\title{
Graves Disease Induced by Radioiodine Therapy for Toxic Nodular Goiter: A Case Report
}

\author{
Toksik Nodüler Guatrda Radyoaktif lyot Tedavisinin Neden Olduğu Graves Hastalığl: \\ Olgu Sunumu
}

Yakup Yürekli1, Arzu Cengiz'1, Engin Güney²

IAdnan Menderes University Faculty of Medicine, Department of Nuclear Medicine, Aydın, Turkey

2Adnan Menderes University Faculty of Medicine, Department of Endocrinology, Aydın, Turkey

\begin{abstract}
Graves' disease (GD) may be observed as an infrequent adverse effect after radioiodine therapy (RAIT) for toxic thyroid adenoma (TA) and toxic multi nodular goiter (MNG). We present a case of a 55-year-old male with a toxic nodule who was treated with RAI. After therapy, the patient's serum free triiodothyronine (fT3) and free thyroxine (fT4) levels gradually increased. Antithyroid peroxidase (TPOAb), antithyroglobulin (TgAb) and TSH-receptor antibodies (TRAb) were also positive. Thyroid scintigraphy revealed diffuse intense uptake after four months of RAIT. Radiation-induced GD should be considered in patients with aggravated hyperthyroidism 3-4 months after therapy.
\end{abstract}

Keywords: Nodular goiter, Graves' disease, iodine radioisotopes

\begin{abstract}
Öz
Toksik adenom (TA) ve multi nodüler guatr (MNG) tedavisi için radyoaktif iyot (RAi) uygulanmasını takiben nadir bir yan etki olarak Graves hastalığı görülebilir. Bu olguda RAi ile tedavi edilen, toksik nodülü olan 55 yaşındaki bir erkek hasta sunulmaktadır. Tedavi sonrası hastanın serbest triiyodotironin (fT3) ve serbest tiroksin (fT4) düzeylerinde giderek artış görüldü. Antitiroid peroksidaz (TPOAb), antitiroglobulin (TgAb) ve TSH-reseptor antikorları (TRAb) pozitif idi. RAi tedavisinden 4 ay sonra yapılan tiroid sintigrafisi diffüz artmış aktivite tutulumu gösterdi. Tedaviden 3-4 ay sonra hipertiroidi bulgu ve belirtilerinde belirginleşme olan hastalarda radyasyona bağlı Graves hastalığı göz önünde bulundurulmalıdır.
\end{abstract}

Anahtar kelimeler: Nodüler guatr, Graves hastalığı, iyot radyoizotopları

\section{Introduction}

Radioiodine therapy (RAIT) is being increasingly used in patients with toxic thyroid adenomas (TA) and multi nodular goiter (MNG). Radiation thyroiditis is a well-known complication that presents with neck pain, dysphagia, thyroid tenderness and transient hyperthyroidism. This adverse effect usually occurs a few days after RAIT $(1,2)$.
Graves' disease (GD) is reported as an uncommon adverse effect after RAIT for TA and MNG, and usually manifests 3 to 6 months after therapy $(3,4,5)$. The incidence of GD following RAIT for MNG was reported as $5 \%$, and this rate is increased upto $22 \%$ in patients who are positive for antithyroid peroxidase antibody (TPOAbs) before treatment $(2,3)$.

Address for Correspondence: Arzu Cengiz MD, Adnan Menderes University Faculty of Medicine, Department of Nuclear Medicine, Aydın, Turkey Phone: +90 2564441256 E-mail: arzukincengiz@gmail.com Received: 23.12.2013 Accepted: 14.02.2014 
Herein, we present a patient with TA who developed GD after treatment with RAI.

\section{Case Report}

A 55-year-old male patient with subclinical hyperthyroidism and TA was referred to our department for RAIT. Baseline fT3 was $4.01 \mathrm{pg} / \mathrm{ml}$ (N: 1.82-4.62 pg/ml), fT4 was $1.61 \mathrm{ng} / \mathrm{dL}$ (N: 0.932-1.71 ng/dL) and TSH was 0.167 $\mu \mathrm{lU} / \mathrm{ml}(\mathrm{N}: 0.270-4.2 \mu \mathrm{lU} / \mathrm{ml}$ ). Thyroid autoantibodies were not evaluated before RAIT. Physical examination revealed diffuse goiter. Ultrasonography showed an enlarged gland and a $13 \mathrm{~mm}$ isoechoic nodule in the left lobe with a few millimetric nodules in the right lobe. Fine-needle aspiration biopsy was interpreted as benign. Thyroid scintigraphy revealed an enlarged gland and a hyperactive area corresponding to the left lobe nodule and mild suppression in the remainder of the gland (Figure 1). RAIT was planned as soon as possible due to his cardiac problems. He was treated with a fixed dose of $10 \mathrm{mCi}$ of $\mathrm{I}-131$. His thyroid function tests in the post-treatment follow-up are shown in Table 1. TPOAbs, TgAbs and TRAbs were positive 4 months after therapy. The patient complained of irritability and anxiety. Thyroid scintigraphy showed an enlarged gland with diffusely increased uptake (Figure 2). Although spontaneous development of GD cannot be excluded, we believe that the autoimmune response of thyroid follicular cells after RAl treatment resulted in GD.

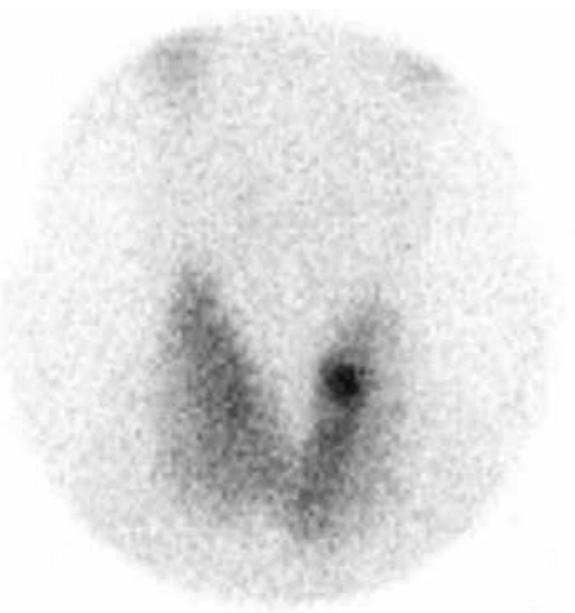

Figure 1. Pre-treatment thyroid scintigraphy showing hyperactive nodule on the left lobe and mild suppression in the remainder of the gland

Table 1. Results of thyroid function tests in the posttreatment follow-up

\begin{tabular}{llll}
\hline & $\mathbf{s T 3}(\mathbf{p g} / \mathbf{m l})$ & $\mathbf{s T 4}(\mathbf{n g} / \mathbf{d L})$ & TSH $(\boldsymbol{\mu l U} / \mathbf{m l})$ \\
1st month & $5.15(\uparrow)$ & $1.67(\mathrm{~N})$ & $0.013(\downarrow)$ \\
$3^{\text {rd }}$ month & $13.2(\uparrow)$ & $5.12(\uparrow)$ & $0.004(\downarrow)$ \\
$4^{\text {th }}$ month & $13.8(\uparrow)$ & $5.30(\uparrow)$ & $0.004(\downarrow)$
\end{tabular}

\section{Literature Review and Discussion}

The transition of a toxic nodular goiter into an autoimmune toxic goiter as a side effect of RAIT has previously been described in case reports, as well as prospective and retrospective studies $(2,3,4,6,7)$. This side effect occurs in as many as $5 \%$ of patients with nodular goiter who were treated with I-131 (2). Several pathophysiological mechanisms were suggested to explain the development of autoimmune hyperthyroidism after RAIT. It has been reported that RAIT induced an increase in thyroid-stimulating immunoglobulins within the circulation $(1,8)$. Another mechanism is radiation-induced impairement of immune balance between T-helper and suppressor lymphocytes (9).

Schmidt et al. (10) concluded that patients with elevated TPOAbs before RAIT had an almost 10-fold higher risk of developing post-therapy immunogenic hyperthyroidism. In another study, authors indicated that patients with high serum TPOAb levels before RAIT seem to be at increased risk of developing delayed TRAb-associated hyperthyroidism as well as hypothyroidism. Therefore, they suggested that I-131 treatment should be used in selected patients with elevated TPOAb levels (1).

Although such cases are rare, the occurrence of GD by destruction of follicular cells have also been described after percutaneous ethanol injection, external radiation for nonthyroidal diseases, subacute thyroiditis, and surgical resection of autonomous adenoma or parathyroidectomy $(11,12,13,14,15)$.

It is concluded that physicians should recognize GD as a side effect of RAIT for toxic nodular goiter. The risk assessment should include evaluation of pretreatment TPOAb levels. Patients with increasingly evident hyperthyroidism 3-4 months after RAIT should be investigated for the development of GD.

Figure 2. Thyroid scintigraphy 4 months after radioiodine therapy showing diffuse increased uptake 
Informed Consent: It was taken, Concept: Yakup Yürekli, Design: Yakup Yürekli, Data Collection or Processing: Engin Güney, Yakup Yürekli, Arzu Cengiz, Analysis or Interpretation: Engin Güney, Yakup Yürekli, Arzu Cengiz, Literature Search: Arzu Cengiz, Writing: Yakup Yürekli, Arzu Cengiz, Peer-review: Externally peerreviewed, Conflict of Interest: No conflict of interest was declared by the authors, Financial Disclosure: The authors declared that this study has received no financial support.

\section{References}

1. Nygaard $B$, Knudsen JH, Heqedüs $L$, Scient AV, Hansen JE. Thyrotropin receptor antibodies and Graves' disease, a sideeffect of 131 I treatment in patients with nontoxic goiter. J Clin Endocrinol Metab 1997;82:2926-2930.

2. Nygaard B, Faber J, Veje A, Heqedüs L, Hansen JM. Transition of nodular toxic goiter to autoimmune hyperthyroidism trigged by 131I therapy. Thyroid 1999;9:477-481.

3. Nygaard B, Faber J, Veje A, Heqedüs L, Hansen JM. Appearance of Graves'-like disease after radioiodine therapy for toxic as well as non-toxic multinodular goitre. Clin Endocrinol (Oxf) 1995;43:129130.

4. Niepomniszcze H, Pitoia F, Goodall C, Manavela M, Bruno OD. Development of Graves' hyperthyroidism after radioiodine treatment for a toxic nodule: is the hyperthyroidism always triggered by 1311 therapy? Thyroid 2001;11:991.

5. Rubio IG, Perone BH, Silva MN, Knobel M, Medeiros-Neto G. Human recombinant TSH preceding a therapeutic dose of radioiodine for multinodular goiters has no significant effect in the surge of $\mathrm{TSH}-$ receptor and TPO antibodies. Thyroid 2005;15:134-139.

6. Van Leussen JJ, Edelbroek MA, Talsma MA, de Heide LJ. Graves' disease induced by $\mathrm{Na}(131)$ therapy for toxic multinodular goitre. Neth J Med 2000;57:194-197.
7. Chiovato L, Santini F, Vitti P, Bendinelli G, Pinchera A. Apperance of thyroid stimulating antibody and Graves' disease after radioiodine therapy for toxic nodular goitre. Clin Endocrinol (Oxf) 1995;40:803806.

8. DeGroot LJ. Radioiodine and immune system. Thyroid 1997;7:259264.

9. Huysmans AK, Hermus RM, Edelbroek MA, Tjabbes T, Oostdijk, Ross HA, Corstens FH, Kloppenborg PW. Autoimmune hyperthyroidism occuring late after radioiodine treatment for volume reduction of large multinodular goiters. Thyroid 1997;7:535-539.

10. Schmidt M, Gorbauch E, Dietlein M, Faust M, Stützer H, Eschner W, Theissen $\mathrm{P}$, Schicha $\mathrm{H}$. Incidence of postradioiodine immunogenic hyperthyroidism/Graves' disease in relation to a temporary increase in thyrotropin receptor antibodies after radioiodine therapy for autonomous thyroid disease. Thyroid 2006;16:281288.

11. Monzani F, Del Guerra P, Caraccio N, Casolaro A, Lippolis PV, Goletti O. Appearance of Graves' disease after percutaneous ethanol injection for the treatment of hyperfunctioning thyroid adenoma. J Endocrinol Invest 1997;20:294-298.

12. Verde G. Graves' disease after percutaneous ethanol injection for the treatment of autonomous thyroid adenoma. J Endocrinol Invest 1998;21:334-335.

13. Williams ED. Biologic effects of radiation on the thyroid. In: Braverman LE, Utiger RD, (eds). Werner and Ingbar's the thyroid, a fundamental and clinical text, 6th ed. Philadelphia, New York, London, Hagerstown, Lippincott, 1991;421-436.

14. Walfish PG, Caplan D, Rosen IB. Postparathyroidectomy transient thyrotoxicosis. J Clin Endocrinol Metab 1992;75:224-227.

15. Bennedbaek FN, Gram J, Heqedüs L. The transition of subacute thyroiditis to Graves' disease as evidenced by diagnostic imaging. Thyroid 1996;6:457-459. 